\title{
BODY DIAMETERS IN 3 - 6 YEARS OLD CHILDREN FROM PLOVDIV
}

\author{
Slavi Tineshev, Mima Nikolova \\ University of Plovdiv "Paisii Hilendarski", Faculty of Biology, \\ Department of "Human Anatomy and Physiology", \\ 24 Tsar Assen Str., 4000, Plovdiv, Bulgaria \\ e-mail: stineshev@abv.bg
}

\begin{abstract}
Summary
The purpose of the research is to analyze the body diameters in 3-6 year old children. The biacromial diameters were taken as well as the two chest diameters, the bicristal and bitrohanterial diameters in 316 children (157 boys and 159 girls) 3, 4, 5 and 6 years of age attending kindergarten in Plovdiv. The analysis shows that all diameters, with the exception of the bitrohanterial have higher values in boys. The absolute year's increment of the diameters is greater in girls. The growth velocity of the researched features is greatest at the age of 3-4 and 4-5, decreasing at different rates for the different features at the age of 5-6. The only exception is the sagittal chest diameter in both sexes and the bitrohanterial diameters in girls.
\end{abstract}

Key words: body diameters, sexual differences, children

\section{Introduction}

The kids' somatic development is one of the most significant indexes of their health and it reflects their general living conditions. The period between 3-6 is critical for the development of human body and it defines the way the body is formed. The child's body during this stage is most susceptible to both the negative and the positive effects of external factors. (Година, E.3.,2001; Mladenova, S, Nikolova,M., 2002).

The processes of growth and development in kids can be assessed by studying the agerelated changes in body size. The growth dynamics of the somatic characteristics allows an assessment of the deviations caused by bad living conditions or various disorders (Задорожная, Л.В.,1998; Балахонова, Е.И., 1991; Миклашевская Н.Н. 1985). Тhe objective of the present research is to describe body diameters of children within the age range of 3-6.

\section{Material and methods}

The sample comprised 316 children - 157 boys and 159 girls from the kindergartens in Plovdiv. They were devided into 4 groups depending on their age. Using the classical method of Martin-Saller, 1957, each child has had its 5 body diameters measured: the biacromial, transversal and sagittal diameters of the chest, the bicristal and bitrohanterial diameters. 
The quantitative assessment of sex differences is made via the index of sex difference (ISD), calculated according to the formula:

$\mathrm{ISD}=2 \mathrm{x}\left(\mathrm{X}_{\text {males }}-\mathrm{X}_{\text {females }}\right) \times 100 /\left(\mathrm{X}_{\text {males }}+\mathrm{X}_{\text {females }}\right)$

Index values above zero show priority of boys, those below zero - a priority of girls.

The absolute year's increment and the growth velocity are calculated for each anthropometric index using the formula:

$$
(\mathrm{X} 2-\mathrm{X} 1) \mathrm{x} 100 / \mathrm{X} 2+\mathrm{X} 1
$$

The data has been statistically processed by means of applying the descriptive analysis. Significant differences between the age and sex groups are assessed by means of t-test of Student at $\mathrm{P}<0.05$

\section{Results and Discussion}

\section{Chest diameters (Table 1, 2, 3; Fig. 2, 3)}

The transversal diameter of the chest is greater in boys and the differences are statistically significant in children 3, 5, and 6 years of age. Within the period from 3 to 6 years of age, this diameter increases by $1.6 \mathrm{~cm}$ in both sexes.

The sagittal diameter of the chest has significantly higher values in boys as compared to girls aged 3 to 6 . Throughout the age span this diameter increases by $1.8 \mathrm{~cm}$ in boys and 2 $\mathrm{cm}$ in girls.

The results of the chest measurements show that in the studied age span the chest grows with almost the same intensity in both sexes in the widthwise direction and the frontalposterior one.

\section{Pelvis diameters (Table 1,2,3; Fig.4,5)}

The bicristal and bitrohanterial diameters in both sexes increase with the age, the bicristal diameter being greater in boys and the bitrochanterial - in girls. Sex differences of the two diameters are not statistically significant. Whereas for boys the two pelvis diameters increase by $2.6 \mathrm{~cm}$, in girls the bitrohanterial increases more than the bicristal diameter.

The biacromial diameter, which characterizes shoulder breadth, shows similar values in both sexes, although it is slightly greater in boys (Table 1,2,3; Fig.1). The difference in the group of the four-year-olds is statistically significant. The total increment is the same in both sexes. / $4.2 \mathrm{~cm}$. /

\section{Growth velocity (Table 4; Fig.6,7,8)}

The growth velocity of biacromial diameter is greatest at the age of 3 and 4 in boys, and the age of 3 to 5 in girls. At the end of the age span, however, the growth intensity is almost the same in both sexes.

The growth velocity of the chest diameters is different. Whereas the

transversal diameter grows more intensively between the age of 4 and 5 in boys, for girls this happens at the age of 3 and 4 .

The growth velocity of the sagittal diameter in boys increases with age and is therefore greatest at the end of the age span. For girls it grows intensively both in the beginning and at the end of the age period.

The growth velocity of the pelvic diameters shows marked differences between the two sexes only in the bitrohanterial diameter. Whereas the bicristal diameter grows most intensively at the age 4 and 5 for both sexes, the growth velocity of the bitrohanterial diameter in boys decreases with age, while it increases in girls. 


\section{Sexual differences (Table 5; Fig.9)}

The analysis of the ISD values shows that sexual differences are most prominent in chest diameters - between 1.95 index units and $5.66 \mathrm{IU}$ with a priority for boys. The greatest differences are recorded in the transversal diameter in five-year-olds and in the sagittal diameter in three-year-olds.

The pelvic diameters exhibit interesting results concerning sexual differences in the bitrochanterial diameter, where the index values show priority for girls. The results are indicative of structural differences in this area.

Table 1. Statistical data about the investigated diameters - boys

\begin{tabular}{|c|c|c|c|c|c|c|c|c|c|c|c|}
\hline \multirow{3}{*}{ 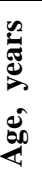 } & \multicolumn{11}{|c|}{ BOYS } \\
\hline & \multirow[t]{2}{*}{$\mathbf{n}$} & \multicolumn{2}{|c|}{$\begin{array}{c}\text { Biacromial } \\
\text { diameter }\end{array}$} & \multicolumn{2}{|c|}{$\begin{array}{c}\text { Transversal } \\
\text { chest diameter }\end{array}$} & \multicolumn{2}{|c|}{$\begin{array}{l}\text { Sagital chest } \\
\text { diameter }\end{array}$} & \multicolumn{2}{|c|}{$\begin{array}{l}\text { Bicristal } \\
\text { diameter }\end{array}$} & \multicolumn{2}{|c|}{$\begin{array}{l}\text { Bitrohanterial } \\
\text { diameter }\end{array}$} \\
\hline & & $\underline{\mathbf{x}}$ & SD & $\mathbf{x}$ & SD & $X$ & SD & $\mathbf{x}$ & SD & $\mathbf{x}$ & SD \\
\hline 3 & 25 & 19,3 & 1,1 & $15,1^{*}$ & 0,5 & $10,9^{*}$ & 1,3 & 14,9 & 0,6 & 15,5 & 0,5 \\
\hline 4 & 38 & $21,1^{*}$ & 1,2 & 15,5 & 0,9 & 11,3 & 1 & 15,5 & 1,1 & 16,4 & 1 \\
\hline 5 & 44 & 22,3 & 1,8 & $16,3^{*}$ & 1,3 & 11,8 & 1,2 & 16,8 & 1,5 & 17,2 & 1,3 \\
\hline 6 & 50 & 23,5 & 1,9 & $16,8^{*}$ & 1,9 & $12,7^{*}$ & 1,5 & 17,5 & 1,3 & 18,1 & 1,4 \\
\hline
\end{tabular}

$\mathrm{P} \leq 0.05(\hat{\delta} / 9)$

Table 2. Statistical data about the investigated diameters - girls

\begin{tabular}{|c|c|c|c|c|c|c|c|c|c|c|c|}
\hline \multirow{3}{*}{ 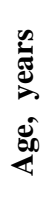 } & \multicolumn{11}{|c|}{ GIRLS } \\
\hline & \multirow[t]{2}{*}{$\mathbf{n}$} & \multicolumn{2}{|c|}{$\begin{array}{l}\text { Biacromial } \\
\text { diameter }\end{array}$} & \multicolumn{2}{|c|}{$\begin{array}{l}\text { Transversal } \\
\text { chest } \\
\text { diameter }\end{array}$} & \multicolumn{2}{|c|}{$\begin{array}{l}\text { Sagital chest } \\
\text { diameter }\end{array}$} & \multicolumn{2}{|c|}{$\begin{array}{l}\text { Bicristal } \\
\text { diameter }\end{array}$} & \multicolumn{2}{|c|}{$\begin{array}{l}\text { Bitrohanterial } \\
\text { diameter }\end{array}$} \\
\hline & & $\mathbf{x}$ & SD & $\mathbf{x}$ & SD & $\mathbf{x}$ & SD & $\mathbf{x}$ & SD & $\mathbf{x}$ & SD \\
\hline 3 & 25 & 19 & 1,3 & $14,6^{*}$ & 1,3 & $10,3^{*}$ & 1,3 & 14,7 & 1,5 & 15,7 & 1 \\
\hline 4 & 34 & $20,4 *$ & 1,2 & 15,2 & 0,8 & 11 & 0,7 & 15,1 & 0,9 & 16,6 & 0,8 \\
\hline 5 & 50 & 21,8 & 1,5 & $15,6^{*}$ & 1,3 & 11,5 & 0,9 & 16,5 & 1,2 & 17,6 & 1,2 \\
\hline 6 & 50 & 23,2 & 1,7 & $16,2^{*}$ & 1,7 & $12,3^{*}$ & 1,1 & 17,1 & 1,9 & 18,8 & 1,9 \\
\hline
\end{tabular}

$\mathrm{P} \leq 0.05(\hat{\jmath} / q)$

Table 3. Year's increment

\begin{tabular}{|c|c|c|c|c|c|c|c|c|c|c|}
\hline \multirow[t]{2}{*}{$\stackrel{\infty}{\infty}$} & \multicolumn{2}{|c|}{$\begin{array}{c}\text { Biacromial } \\
\text { diameter }(\mathrm{cm})\end{array}$} & \multicolumn{2}{|c|}{$\begin{array}{c}\text { Transversal } \\
\text { chest } \\
\text { diameter }(\mathbf{c m})\end{array}$} & \multicolumn{2}{|c|}{$\begin{array}{l}\text { Sagital chest } \\
\text { diameter } \\
(\mathbf{c m})\end{array}$} & \multicolumn{2}{|c|}{$\begin{array}{c}\text { Bicristal } \\
\text { diameter } \\
(\mathrm{cm})\end{array}$} & \multicolumn{2}{|c|}{$\begin{array}{l}\text { Bitrohanterial } \\
\text { diameter }(\mathbf{c m})\end{array}$} \\
\hline & Boys & Girls & Boys & Girls & Boys & Girls & Boys & Girls & Boys & Girls \\
\hline 3 & 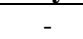 & - & - & - & - & - & - & - & - & - \\
\hline 4 & 1,8 & 1 & 0,4 & 0,6 & 0,4 & 0,7 & 0,6 & 0,4 & 0,9 & 0,9 \\
\hline 5 & 1,3 & 1,5 & 0,8 & 0,4 & 0,5 & 0,5 & 1,3 & 1,4 & 0,8 & 1 \\
\hline 6 & 1,2 & 1,3 & 0,5 & 0,6 & 0,9 & 0,8 & 0,7 & 0,6 & 0,9 & 1,2 \\
\hline
\end{tabular}


Table 4. Growth velocity

\begin{tabular}{|c|c|c|c|c|c|c|c|c|c|c|}
\hline \multirow{2}{*}{ 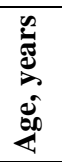 } & \multicolumn{2}{|c|}{$\begin{array}{c}\text { Biacromial } \\
\text { diameter (\%) }\end{array}$} & \multicolumn{2}{|c|}{$\begin{array}{c}\text { Transversal } \\
\text { chest } \\
\text { diameter }(\%)\end{array}$} & \multicolumn{2}{|c|}{$\begin{array}{c}\text { Sagital chest } \\
\text { diameter } \\
(\%)\end{array}$} & \multicolumn{2}{|c|}{$\begin{array}{c}\text { Bicristal } \\
\text { diameter } \\
(\%)\end{array}$} & \multicolumn{2}{|c|}{$\begin{array}{l}\text { Bitrohanterial } \\
\text { diameter }(\%)\end{array}$} \\
\hline & Boys & Girls & Boys & Girls & Boys & Girls & Boys & Girls & Boys & Girls \\
\hline 3 & - & - & - & - & - & - & - & - & - & - \\
\hline 4 & 4,4 & 3,5 & 1,3 & 2 & 1,8 & 3,2 & 1,9 & 1,3 & 2,8 & 2,7 \\
\hline 5 & 2,8 & 3,6 & 2,5 & 1,3 & 2,2 & 2,2 & 4 & 4,4 & 2,3 & 2,9 \\
\hline 6 & 2,6 & 2,9 & 1,5 & 1,8 & 3,6 & 3,3 & 2 & 1,8 & 2,5 & 3,2 \\
\hline
\end{tabular}

Table 5. Sexual differences according to the ISD data

\begin{tabular}{|c|c|c|c|c|c|}
\hline Age & $\begin{array}{c}\text { Biacromial } \\
\text { diameter }\end{array}$ & $\begin{array}{c}\text { Transversal } \\
\text { chest } \\
\text { diameter }\end{array}$ & $\begin{array}{c}\text { Sagital chest } \\
\text { diameter }\end{array}$ & $\begin{array}{c}\text { Bicristal } \\
\text { diameter }\end{array}$ & $\begin{array}{c}\text { Bitrohanterial } \\
\text { diameter }\end{array}$ \\
\hline $\mathbf{3}$ & 1,65 & 3,36 & 5,66 & 1,35 & $-1,28$ \\
\hline $\mathbf{4}$ & 3,37 & 1,95 & 2,69 & 2,61 & $-1,21$ \\
\hline $\mathbf{5}$ & 2,26 & 4,38 & 2,57 & 1,8 & $-2,29$ \\
\hline $\mathbf{6}$ & 1,28 & 3,63 & 3,2 & 2,31 & $-1,89$ \\
\hline
\end{tabular}

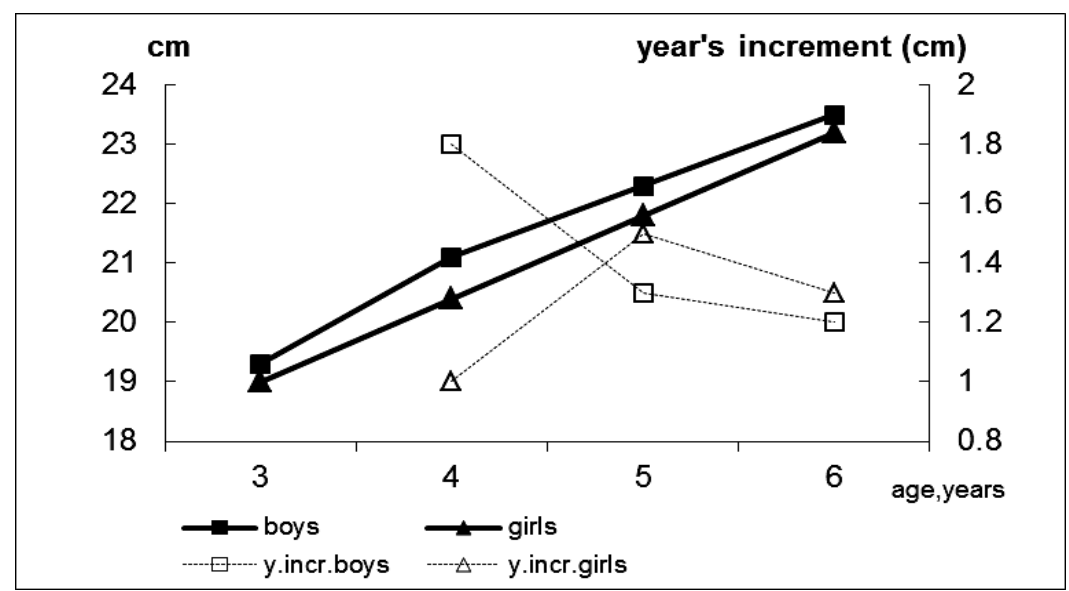

Figure 1. Biacromial diameter 


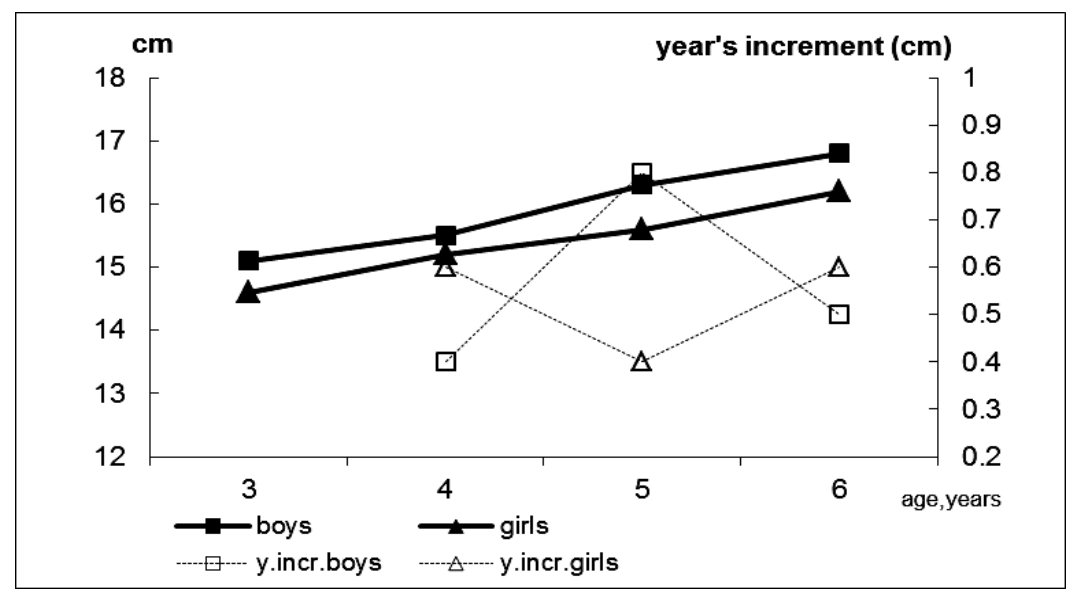

Figure 2. Transversal chest diameter

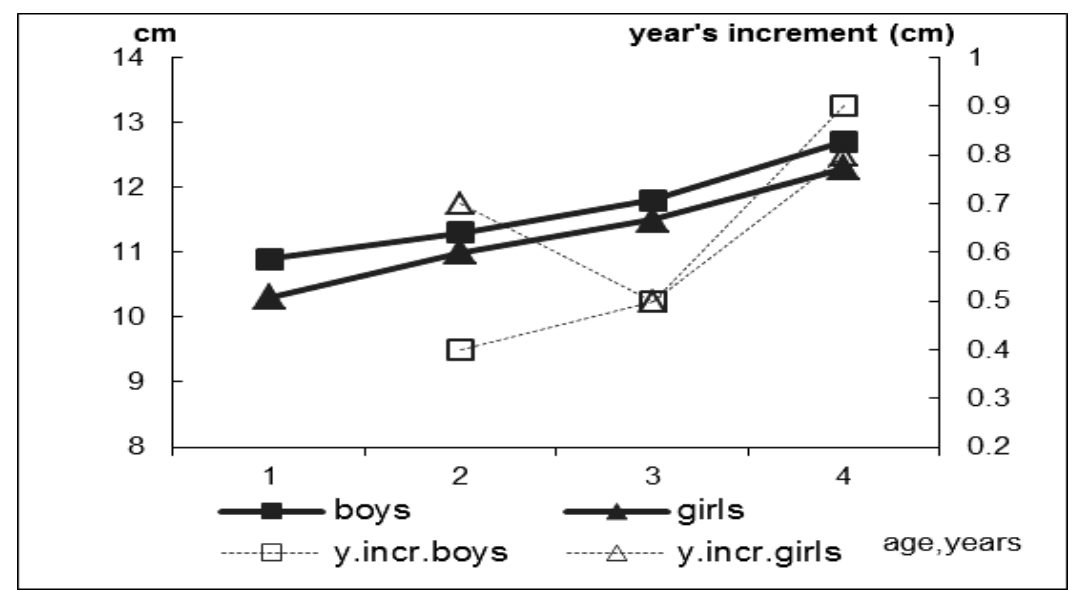

Figure 3. Sagital chest diameter 


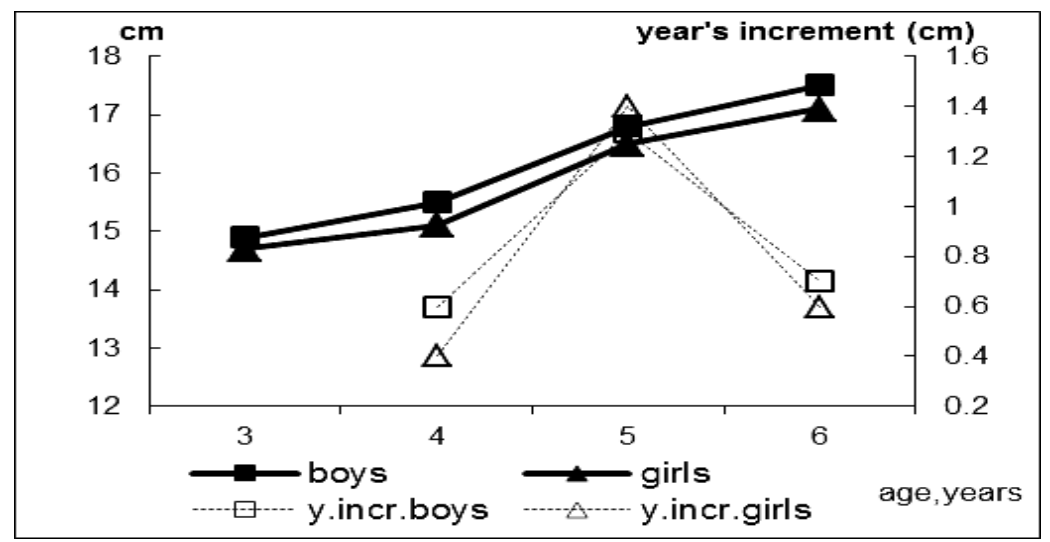

Figure 4. Bicristal diameter

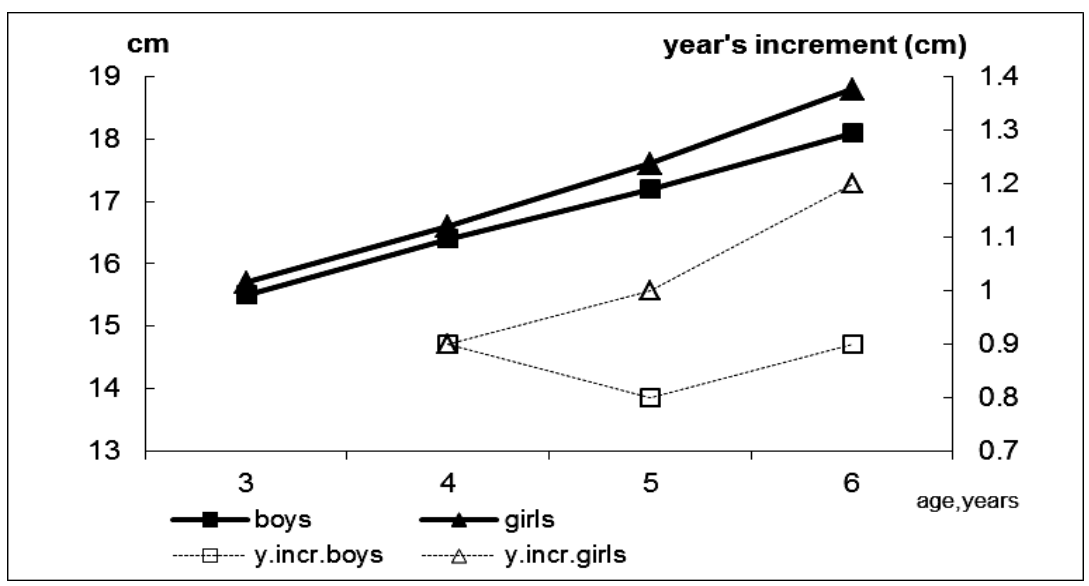

Figure 5. Bitrohanterial diameter

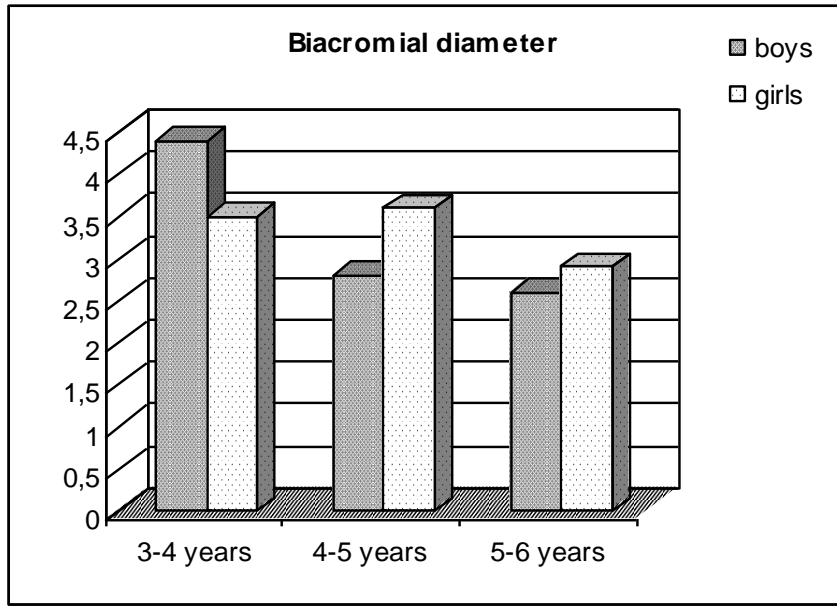

Figure 6. Growth velocity 


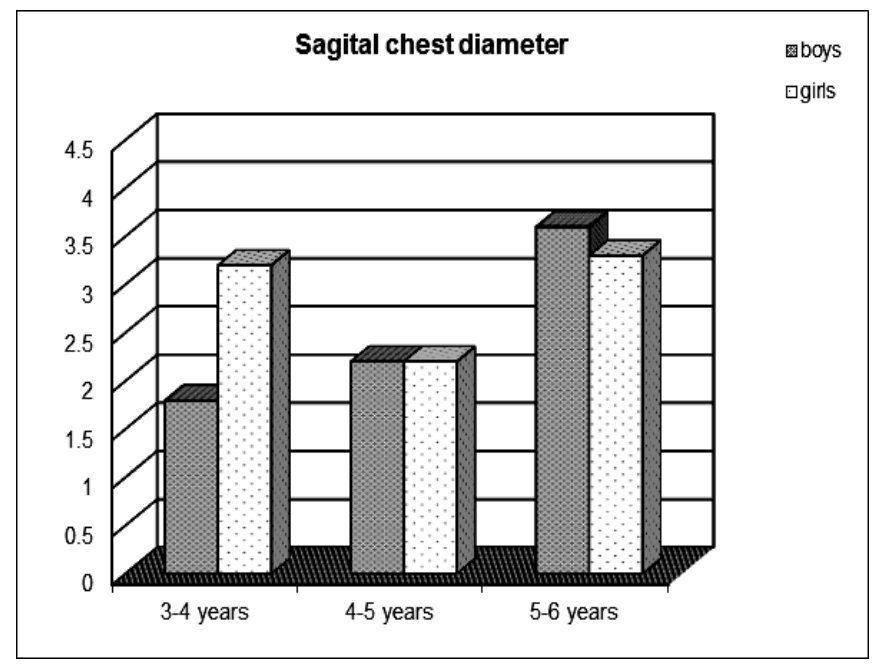

Figure 7. Growth velocity

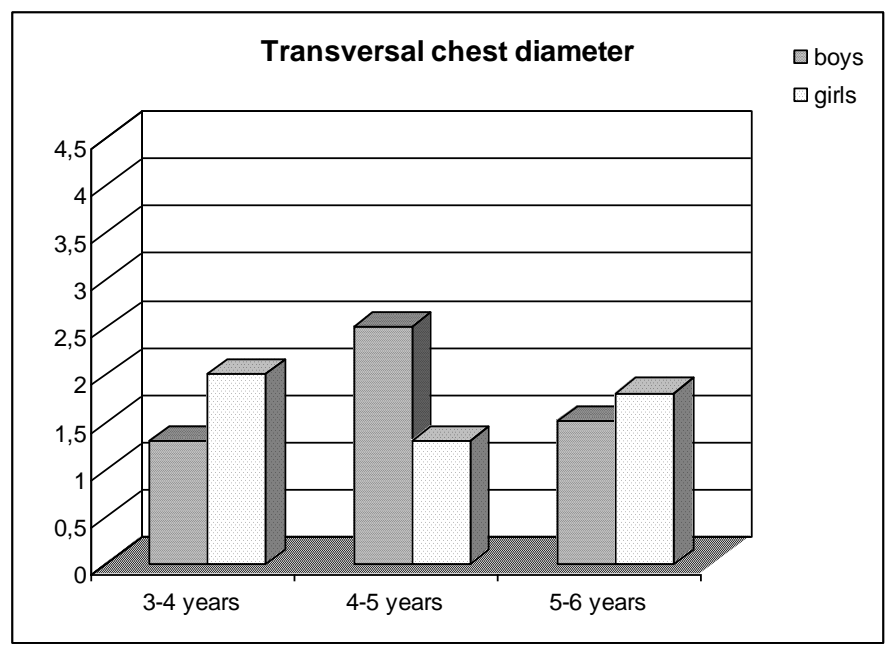

Figure 8. Growth velocity 


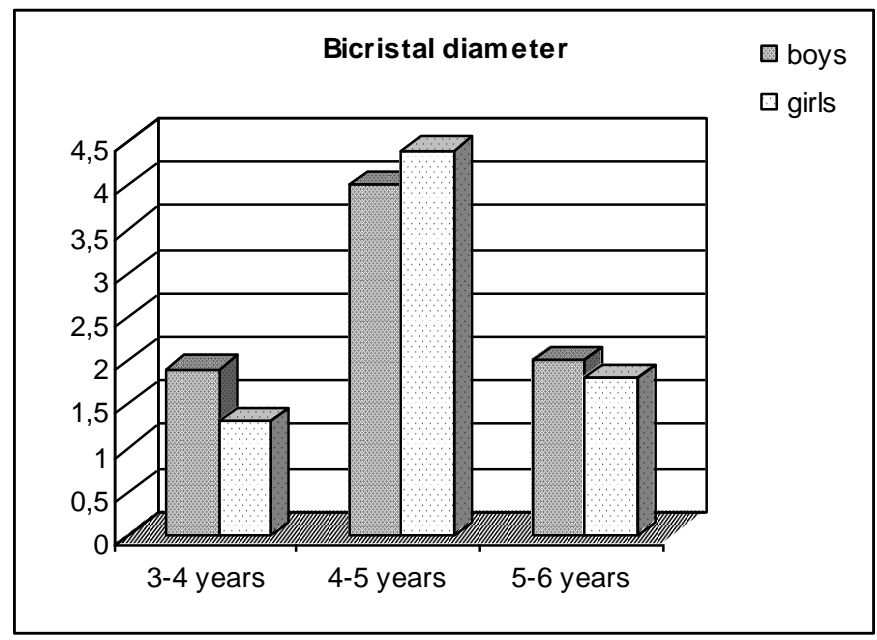

Figure 9. Growth velocity

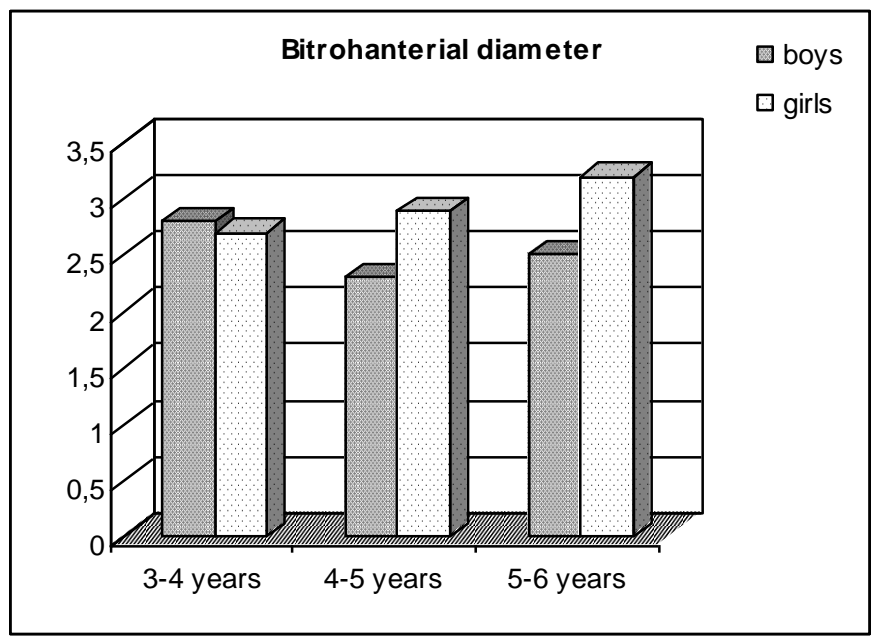

Figure 10. Growth velocity 


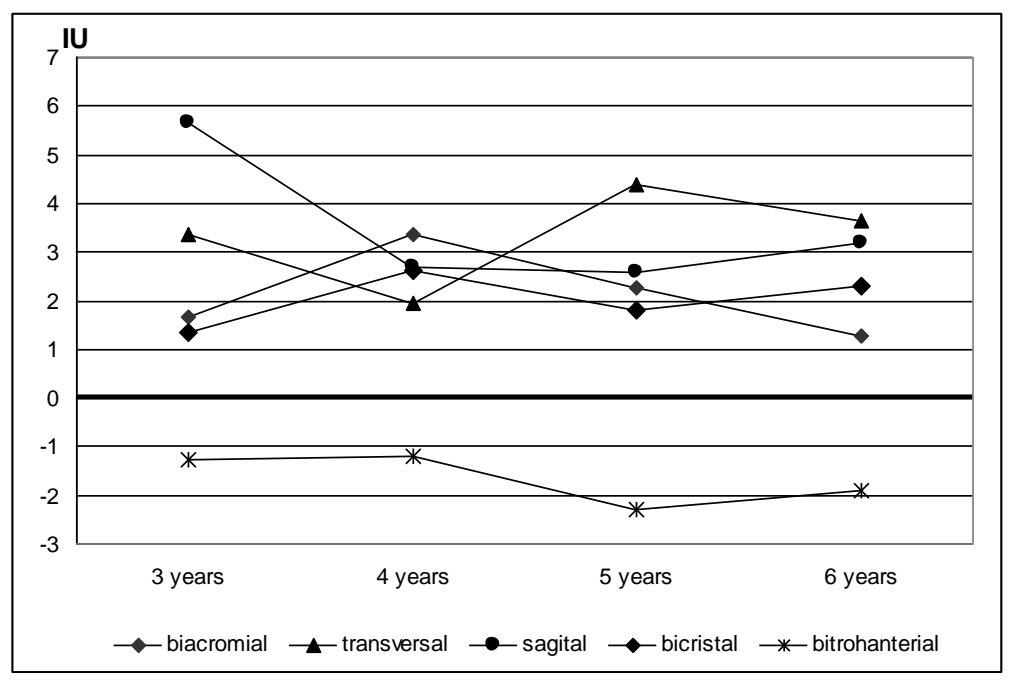

Figure 11. ISD - data about the investigated diameters

\section{Conclusions}

In the researched age span boys have higher values of the researched diameters with the exception of the bitrochanterial diameter. The absolute year's increment of the researched parameters is a bit higher in girls.

The growth velocity is highest between the ages of 3 and 5. At the age of 5 and 6 it decreases in various degrees for the different characteristics with the exception of the sagittal chest diameter in both sexes and the bitrochanterial diameter in girls.

\section{References}

Балахонова ЕИ. Изменчивость соматических параметров у девочек в группах разного биологического возраста в период детство. Автореф. канд.биол.наук, Москва, 1991, с.20.

Година Е3. Динамика процессов роста и развития у человека: пространственно - времевые аспекты. Автореф.докт.биолог.наук, Москва, 2001, с.325.

Миклашевская НН. Ростовые процессы у детей и подростков различных этно-териториальных групп. Дис. Докт. биол. наук - М, 1985, с. 389.

Martin R, Saller K. Lehrbuch der Anthropologie in sistematischer Darstellung. Bd.I, Stuttgart, Gustav Fischer Verlag, 1957.

Mladenova S, Nikolova M.. Intragroup differences in morphological characteristics in children and adolescents from Smplyan region.Journ. of Anthropology, 2002, 4:55-58.

Задорожная ЛВ. Влияние социально-экономических факторов на морфофункциональные карактеристики детей и подростков. Дисерт.канд.биол.наук, Москва, 1998, с.101. 


\title{
TELESNI DIJAMETRI KOD DECE STAROSTI 3 - 6 GODINA IZ PLOVDIVA
}

\author{
Slavi Tineshev, Mima Nikolova
}

\begin{abstract}
Sažetak
Cilj istraživanja je da se analiziraju telesni dijametri dece starosti od 3 do 6 godina. Uzeti su biakromijalni dijametri, kao i dva grudna dijametra, bikristalni i bitrohanterijalni dijametri kod 316 ispitanika (157 dečaka i 159 devojčica) starosti od 3, 4, 5 i 6 godina koji pohađaju obdanište u Plovdivu. Analiza pokazuje da su svi dijametri, sa izuzetkom bitrohanterijalnog većih vrednosti kod dečaka. Apsolutni godišnji prirast dijametra je veći kod devojčica. Brzina rasta ispitivanih karakteristika je najveća na uzrastu od 3-4 i 4-5 godina, smanjujući se različitim stopama za različite karakteristike u starosti od 5-6 godina. Jedini izuzetak je sagitalni dijametar grudi kod oba pola i bitrohanterijalni dijametar kod devojčica.

Ključne reči: telesni dijametri, polne razlike, deca
\end{abstract}

